\title{
The Disappearance of Canada: Margaret Atwood's Transnational Turn and Ustopianism
}

Alberto Braz (University of Alberta)

Recebido 28 mai. 2013/Aprovado 13 mar. 2014

\section{Resumo}

Este artigo analisa a maneira como os romances distópicos recentes de Margaret Atwood, Órix e Crex e $\mathrm{O}$ ano do dilúvio, refletem uma virada para o transnacional na sua ficção, que é significante em relação aos seus escritos antigos $e$ à sua imagem pública de nacionalista cultural Canadense.

Palavras-chave: nacionalismo cultural; continentalismo; distopia; a virada transnacional. 
Margaret Atwood has long been considered one of the giants of Canadian cultural nationalism. From the beginning of her career in the 1960s, she has passionately asserted the need to give voice to the Canadian experience. Even more germane, in her 1972 best-selling monograph Survival: A Thematic Guide to Canadian Literature, she maintains that a national literature plays a pivotal role in a country's life since it is not just "a mirror" but also "a map, a geography of the mind" (ATWOOD, 2004d, p. 26). Thus it is rather surprising that early in the twenty-first century when she writes her dystopian novels about the near-destruction of the world, Oryx and Crake (2003) and The Year of the Flood (2009), and sets them mainly in what used to be North America, she elects not to explore how Canada is directly affected by the calamity. More striking, while characters in what was once the United States still have some remnants of collective memory about their old country, no one seems to remember what Canada was like. One possible explanation is that Oryx and Crake and The Year of the Flood are political allegories about how the North American Free Trade Agreement of 1994 - which eliminated barriers to trade and investment among the United States, Canada, and Mexico - led to the dissolution of Canada. However, a more plausible scenario is that the novels are really the literary equivalents of the sociopolitical and economic forces that the citizen Atwood so vociferously opposes. As I will argue in my essay, there is a major conflict not only between Atwood the citizen and Atwood the writer but also between the early Atwood and the more recent one. In short, Atwood appears to have undergone a transnational turn that clashes overtly both with her public political image and with her early work.

I must confess that I am somewhat uncomfortable with the idea of assessing the first two installments of the MaddAddam Trilogy by focusing not on what its author has done but on what she has not done. As Atwood (1982) asserts in her essay "Northrop Frye Observed," "The critic's job is not to tell poets what to do, but to tell readers what they have done" (p. 401). The complication is that Atwood is a writer as well as a critic, and possesses at least two separate professional personas. Moreover, as a critic, she is someone who can be quite categorical about what writers ought to do (cf. BRAZ, 2010). So it seems fair to apply her own critical criteria to her fiction. For instance, in Survival, she states that a national literature is significant because "a country needs to hear its own voices, if it is to become or to remain an aware society 
and a functioning democracy" (ATWOOD, 2004d, p. 12). No less important, she contends that "a writer's job is to tell his society not how it ought to live, but how it does live" (ATWOOD, 2004d, p. 53). The early Atwood of Survival - a book that she keeps revisiting (1999b; 2012b) - demands that writers engage with their own societies. But this is precisely what she does not do in Oryx and Crake and The Year of the Flood. Both novels, as noted, are set mainly in what used to be North America. Yet, unless one performs that not untypical Canadian move of extrapolating from the US experience and assuming that it also applies to Canada, it is impossible to discern how Canada was affected by the viral outbreak that almost wipes out the world's population. Or, alternatively, one is forced to deduce that, by the time the two novels occur, Canada has vanished without a trace.

Needless to say, the idea that Canada might disappear in the future is not unfathomable. Atwood (2004d) actually has written that it is a rather "Canadian" trait not just "to ponder our own potential disappearance" but to do so with "gloomy pleasure" (p. 12). That is, like other collectivities, Canadians appear to get a kick from contemplating their own apocalypse. But as I stated at the outset, my suspicion is that the absence of Canada in Atwood's most recent dystopias has less to do with the country's future than with its present, the fact that it is part of a powerful world system, most conspicuously reflected in its cultural capital being located outside the country's geographical borders.

One of the most fruitful aspects of Pascale Casanova's The World Republic of Letters (La république mondiale des lettres) is her focus on the international dimension of literary space. On the one hand, Casanova (2004) maintains that literature possesses "a tendency toward autonomy, which is to say literary emancipation in the face of political (and national) claims to authority" (p. 39). On the other hand, though, she contends that, despite its emancipatory nature, the world of literature is not only highly stratified but violently so. As she writes, "The simple idea that dominates the literary world still today, of literature as something pure and harmonious, works to eliminate all traces of the invisible violence that reigns over it and denies the power relations that are specific to this world and the battles that are fought in it" (CASANOVA, 2004, p. 42-43). For Casanova, this violence is most evident in the fact that the literatures that comprise any literary system are unequal and those from the centre, or capital, have considerably more power than the ones from the periphery. After all, for market reasons as well as cultural cachet, peripheral literatures need to be accepted by the centre, and only certain cultures have the power to confer either prestige or legitimacy on other cultures (DENNISON \& LIM, 2006, p. 2). Again, Casanova suggests that there are chosen literatures the way there are chosen peoples. 
Unfortunately for English-speaking Canada and Québec, neither literature is one of them.

Atwood is obviously aware of the inequities of international literary space, and how they inevitably shape a literature like Canada's. In a recent interview, she affirms that "Canadians always had to be international. We always have had one foot in a pond here and one foot in a pond over there because we weren't big enough to not be international" (ATWOOD, 2012a, p. 68). This reality, it goes without saying, is neither new nor limited to English Canada. For example, in the early 1940s, the influential editor Ellen Elliott (1941) observes that "the Canadian market alone is not enough" and that before Canadians "can become really national in our writing - and that, I feel, is the aim of all conscientious writers - we must become international in our way of thought" (p. 5). Similarly, in a letter to Hugh MacLennan in the mid-1960s, the celebrated US novelist and critic Edmund Wilson (1977) remarks that MacLennan has made him "realize how much you people up there are still groping for an audience. I suppose that that is the reason that so many French Canadian novels are laid in an unspecified locality. They hope to be read in France, but what they write is alien to the French, and their stories can't be imagined as taking place anywhere except in French Canada" (p. 634). In other words, peripheral literatures are always profoundly shaped by the hierarchies within their literary space, which may explain the curious geocultural focus of Atwood's MaddAddam dystopias.

Atwood herself writes in an essay on Canada-US relations in the 1980s, "Colonies breed something called 'the colonial mentality,' and if you have the colonial mentality you believe that the great good place is always somewhere else" (ATWOOD, 1982, p. 382). However, it is likely that the colonial mindset leads people to think that it is not only great things that always happen elsewhere but all world-historical events, including catastrophic ones. This would elucidate why many writers from non-imperial cultures often come to see the world from the perspective of the centre of their literary system. In the case of Atwood, even though Survival became a best-seller in Canada, she could not get it published in the United States. As her New York editor reportedly told her, "'Listen sweetie, Canada is death down here" (ATWOOD, 1982, p. 387), which anticipates the comment by the Baltimore taxi driver in Esi Edugyan's novel Half-Blood Blues that serves as the epigraph for this essay, "Canada kills any conversation quick, I learned long ago" (2011, p. 35). It certainly does not seem to have been by accident that Atwood "graduated" from "being world-famous in Canada to being world-famous, sort of, in the way that writers are," after she wrote The Handmaid's Tale, which is set largely in the United States (ATWOOD, 2004b, p. 5). Significantly, unlike her more recent dystopias, The Handmaid's Tale not only 
acknowledges the international border between Canada and the United States but portrays it as a symbol of cultural and political difference, offering people an alternative, the possibility of getting "out of the country" (ATWOOD, 1986, p. 231). This is an option that is no longer available in the MaddAddam novels, underscoring their transnational or continental orientation.

Of course the main reason that the general absence of Canada in Oryx and Crake and The Year of the Flood is noteworthy is that Atwood is someone who is perceived - and who presents herself - as a passionate Canadian cultural nationalist. Atwood may not be bigger than both God and the First Cause, as Al Purdy (2000) suggests in his satirical poem "Concerning Ms. Atwood" (p. 497), but for many people she embodies Canadian culture. Typically, when the University of Calgary honoured Atwood as its 2013 distinguished visiting writer, it described her as "'the Queen of Can-Lit"' (McCOY, 2013). Outside the country, she is also usually seen as "Canada's national treasure" (GAINES, 2012). Particularly when it comes to Canada's place in North America, Atwood has emerged as an anti-continentalist firebrand, declaring during the Free Trade debate in the early 1990s that the matter "has the potential to fragment and destroy the country in a way that nothing else has succeeded in doing" (ATWOOD, 1993, p. 92). From her perspective, her native land has never had a beneficial relationship with its giant neighbour to the south. "Canada as a separate but dominated country," she expounds with her trademark cutting wit, "has done about as well under the U.S. as women worldwide have done under men; about the only position they've ever adopted toward us, country to country, has been the missionary position, and we were not on top" (p. 94). But with Free Trade, argues Atwood, things will only get worse. As she highlights the dangers of unencumbered commerce between such unequal partners, "If it's Washington making the decisions anyway, why deal with the middleman? Why don't we just join them?" (p. 94). If the agreement were accepted, she implies, there would not be a logical reason to have a separate polity at the northern end of the continent. Given her articulation of such apocalyptic visions, it is striking that within a decade Atwood would be producing what has been called "free trade fiction" (HENIGHAN, 2002, p. 133-56). That is, she would be contributing to what she claims is so detrimental for Canada, a transnational culture.

Oryx and Crake is set in an unspecified but not distant future, mainly on the East Coast of North America, in the aftermath of an apocalyptic disaster. As far as the reader is able to discern at the end of the narrative, there are only four human beings left on the planet: the main protagonist Snowman and three strangers whose footprints he finds on a beach. Furthermore, it is not clear what will happen when Snowman meets the two other men, "one brown, one white," and a "tea-coloured woman" (ATWOOD, 
2004c, p. 441). As the novel concludes cryptically, "Zero hour, Snowman thinks. Time to go" (p. 443), an ending that the prominent British literary critic Gillian Beer (2009) would write several years later "has haunted me ever since I read it" (p. F8). The suggestion in the text is that Snowman is probably contemplating making some kind of contact. But even assuming that the strangers do not misjudge his intentions - both they and Snowman are armed with laser guns - humanity's future is far from being assured. After all, there is supposedly only one woman left and she looks famished, "stringy" (ATWOOD, 2004c, p. 442). So if for some reason she is unable to reproduce, it would appear to be the end of the line for homo sapiens.

Throughout Atwood's novel there are numerous indications that humans are a species in trouble, particularly because of environmental degradation, overpopulation, and plain human hubris. As Snowman, also known as Jimmy, is informed by his brilliant scientist friend Crake, "we're running out of space-time. Demand for resources has exceeded supply for decades in marginal geopolitical areas, hence the famines and droughts; but very soon, demand is going to exceed supply for everyone" (ATWOOD, 2004c, p. 356). According to Crake, who used to be known as Glenn, "The tide of human desire, the desire for more and better, would overwhelm [the bulk of humanity]. It would take control and drive events, as it had in every large change throughout history" (p. 357). In addition, the much feared climate change has become a reality and the weather is so warm and wet during the summer that people no longer go on picnics. June has become "the wet season all the way up the east coast" and the elites escape to Moosonee, "on the western shore of Hudson's [sic] Bay ... to beat the heat" (p. 211, 217). No less ominous, global wars and equally global resistance movements break out everywhere. Because of this universal lack of security, the social fabric begins to disintegrate and the elites retreat to high-security enclaves, walled compounds, in which they hope they will be sheltered from the violence of the pleeblands where the majority of the populace lives.

Yet even in the Compounds people are not safe, despite the omnipresence of a private security firm with the ominous name of CorpSeCorps, which eventually displaces the local police forces. In an attempt to solve humanity's problems and perhaps conquer "immortality," Crake develops a revolutionary pill called BlyssPluss, a prophylactic designed to "eliminate the external causes of death" (ATWOOD, 2004c, p. 353, 354). His revolutionary scientific experiments also result in the creation of a new, partly human species called Crakers, who come in "all available skin colours" but in whom the susceptibility to "racism - or, as they referred to it in [the laboratory] Paradice, pseudospeciation - had been eliminated" (p. 363, 366). The BlyssPluss Pill, though, turns out to be considerably less benign than anticipated. Instead of 
preventing death, it generates it en masse, when Crake decides to insert into it a "killer virus" named "JUVE, Jetspeed Ultra Virus Extraordinary" (p. 406). JUVE infects the whole world - catastrophic depopulation through "sexually transmitted" diseases being a trope that is articulated elsewhere in Atwood's work (ATWOOD, 1999a, p. 21). It first surfaces in Brazil and almost immediately materializes around the globe, from Taiwan to Thailand, Saudi Arabia, India, France, Germany, to the "pleeblands west of Chicago" (ATWOOD, 2004c, p. 388). The virus is clearly a manifestation of the age of globalization. As the text explains, "The thing didn't appear to be spreading from city to city: it was breaking out in a number of them simultaneously" (p. 389). Again, it is a universal phenomenon, ruining almost everyone in its wake.

Published six years after Oryx and Crake, The Year of the Flood is less a sequel to the earlier text than a companion to it, what Atwood (2011) calls a "sibling book" (p. 92). While it focuses on the same events, the release of the viral pill JUVE and the consequent apocalyptic destruction, it explores the cataclysm from the point of view of different social groups, notably religious ones, eking a living in the pleeblands. Oryx and Crake, as we have seen, depicts the world from the perspective of the sheltered elites in the Compounds. This is reflected in Crake's contention that "crank religions" are bound not to like his ostensibly sexually liberating BlyssPluss Pill, "in view of the fact that their raison d'être [is] based on misery, indefinitely deferred gratification, and sexual frustration, but they wouldn't be able to hold out long" (ATWOOD, 2004c, p. 357). However, his prognosis proves to be wrong, since many religious individuals never accept the new order of things.

The Year of the Flood was originally entitled God's Gardeners (cf. ATWOOD, 2011, p. 92) and dramatizes the resistance to the Compounds elites by a group of the same name. Founded by a former epidemiologist named Adam One, God's Gardeners develop what can best be described as an ecological religion, as evident in their seraphic pantheon: Saint Dian Fossey, Saint Fairley of Wolves, Saint Jacques Costeau, Saint Rachel Carson, Saint Chico Mendes, and so on. The Gardeners are urban organic farmers. They cover "barren rooftops with greenery," under the conviction that by doing so "we are doing our small part in the redemption of God's Creation from the decay and sterility that lies all around us, and feeding ourselves with unpolluted food in the bargain" (ATWOOD, 2009, p. 11). The Gardeners do not trust writing, producing an Oral Hymnbook in which they safeguard their collective wisdom. As we are informed by one of the survivors, they are afraid of leaving textual "trails" and counsel their members "to depend on memory, because nothing written down could be relied on. The Spirit travels from mouth to mouth, not from thing to thing: books could be burnt, paper crumble away, computers could be destroyed. Only the Spirit lives forever, and 
the Spirit isn't a thing" (p. 6). Perhaps even more significant, the Gardeners do not believe in either free enterprise or science, asserting that the corporations in the Compounds will "produce data and scientists; they'll produce doctors - worthless, they've all been bought" (p. 105). As Adam One tells his followers, "all those scientists and business people...were destroying old Species and making new ones and ruining the world" (p. 146). Furthermore, humans appear to have become a fallen species even before the age of science and economics, because of our sense of superiority toward nonhuman animals and the planet as such. In Adam One's words, "Ours is a fall into greed: why do we think that everything on Earth belongs to us, while in reality we belong to Everything? We have betrayed the trust of the Animals, and defiled our sacred task of stewardship" (p. 52-53). Because of all those transgressions, humanity will be struck with a Waterless Flood.

As so often predicted by the Gardeners, the Waterless Flood does wallop Earth. It is "not an ordinary pandemic" that could "be contained after a few hundred thousand deaths, then obliterated with biotools and bleach" (ATWOOD, 2009, p. 20). Rather, it is a calamity of apocalyptic proportions. The Waterless Flood "travelled through the air as if on wings, it burned through cities like fire, spreading germ-ridden mobs, terror, and butchery. The lights were going out everywhere, the news was sporadic: systems were failing as their keepers died. It looked like total breakdown" (p. 20). Among the few survivors are two young women named Toby and Ren, who escape the virus because they happen to be locked in isolation chambers at the places where they work, a spa and a strip joint respectively. Toby and Ren are associated with God's Gardeners, even if they are not always orthodox believers, and it is largely through them that Atwood reconstructs both life before the cataclysm and the possibility of Earth's eventual "Rebirth!" (p. 371). In fact, what we learn near the end of the novel is that, while the Waterless Flood is a plague, "it is a plague ... that infects no Species but our own, and that will leave all the other Creatures untouched." As Adam One says to the Gardeners, "It is not this Earth that is to be demolished: it is the Human Species. Perhaps God will create another, more compassionate race to take our place" (p. 424). That is, the scourge is aimed exclusively at human beings, which in a paradoxical way still sets humans apart from other life forms, if only in our depravation.

With its focus on the resistance to the Darwinian neoliberalism of the Compounds, The Year of the Flood seems more optimistic than Oryx and Crake. As Atwood stated at the time of the novel's publication, the Waterless Flood is "something like a worldwide outbreak of the Ebola-Marburg virus, producing 'a hemorrhagic, dissolve-from-the-inside kind of fever'" (qtd. in BARBER, 2009, p. R1). But she underlines that her vision of the future "'could be much worse... It could be a nuclear book in which everything is 
grey and burnt'"' (qtd. in BARBER, 2009, p. R5). Besides, Atwood maintains that regardless of how calamitous the future may be, there will always be "music of some kind...It's inevitable. We don't know of a culture without it, therefore we don't know a religion without it" (qtd. in BARBER, 2009, p. R5). This ray of hope is of course represented by God's Gardeners, a group that Beer, (2009) finds "at once exhilarating, absurd and truth-telling" (p. R8). Still, the optimism of The Year of the Flood remains tempered. As the science fiction writer Robert Charles Wilson (2009) points out, the novel "does not offer any easy answers. Both the corporate state and the utopian religion of God's Gardeners are impotent in the face of ecological collapse, the first because it has divorced itself from any sense of responsibility and the second because it offers little more than resignation in the face of disaster and disdain for the works of man" (p. 17). In other words, while there may still be music in our apocalyptic future, it could consist largely of laments.

What both Oryx and Crake and The Year of the Flood do illustrate is the author's problematic relationship with science fiction. Atwood has often insisted that her dystopias are not really science fiction, since for her the genre means "fiction in which things happen that are not possible today - that depend, for instance, on advanced space travel, time travel, the discovery of green monsters on other planets or galaxies, or which contain various technologies we have not yet developed" (ATWOOD , 2004b, p. 102). She asserts that in her futuristic novels "nothing happens that the human race has not already done at some time in the past, or which it is not doing now," and for that reason should be classified as "speculative fiction" (2004b, p. 102, 103; see also ATWOOD, $2004 a$, p. 513 and BARBER, 2009, p. R5). Not surprisingly, this is a position that established science fiction writers like Ursula K. Le Guin and Robert J. Sawyer dismiss out of hand, claiming that "she is indeed writing science fiction" (SAWYER, 2004, p. 211) but that she just "doesn't want the literary bigots to shove her into the literary ghetto (LE GUIN, 2009; see also ATWOOD, 2011, p. 5-7). To put it differently, her reluctance to embrace the science fiction label is a kind of genre snobbism.

Still, despite her disinclination to be associated with science fiction, Atwood does not deny that she produces dystopias, or what she terms ustopias. As she explains in her critical book In Other Worlds: SF and the Human Imagination, "Ustopia is a word I made up by combining utopia and dystopia - the imagined perfect society and its opposite - because, in my view, each contains a latent version of the other" (ATWOOD, 2011, p. 66). Moreover, regardless of what she labels such texts, they have a strong didactic component. In a revealing essay entitled "Writing Utopia," Atwood states that "[d]ystopias are often more like dire warnings than satires, dark shadows cast by the present into the future. They are what will happen to us if we don't pull up our 
socks" (ATWOOD, 2004b, p. 104). Or, as she adds, "It's a sad commentary on our age that we find Dystopias a lot easier to believe in than Utopias: Utopias we can only imagine, Dystopias we've already had" (p. 106). Elsewhere, Atwood suggests that the reason dystopias are so easy to envisage in our time has to do with the state of the planet. She asserts that nature used to be menacing to people, who feared it would kill them. "Now," she remarks, "the situation is reversed: we will kill it, and in so doing so seal our own doom, because you are what you breathe, and we and Nature were joined at the hip all along" (ATWOOD, 2012, p. xi). Atwood has intimated that we live in a degenerate period. In a short piece called "Time Capsule Found on the Dead Planet," she outlines humanity's moral evolution. "In the first age," she writes, "we created gods" (p. 191). Then in "the second age we created money" and in the third, "money became god" (2011, p. 192). Now, in the fourth age, "we created deserts. Our deserts were of several kinds, but they had one thing in common: nothing grew there" (2011, p. 192-93). In short, we have turned our planetary home into a wasteland, and the only thing that might save us is prayer.

That being said, Atwood demonstrates that she is enough of an exponent of science fiction that she appears unable to imagine the world's future from the perspective of a politically peripheral country, such as her native land. Istvan Csicsery-Ronay, Jr. (2002) contends that science-fiction has been empire-centred and that, until now, "we have seen only the science fiction futures of the nations that think they are empires. We must wait to see whether the nations who think they are nations will imagine different futures" (p. 237; see also BRAZ, 2008, p. 24-25). Atwood has hinted at why that might be the case. In an interview with Paris Review, she declares that: "In the center of an empire, you can think of your experience as universal. Outside the empire, or on the fringes of the empire, you cannot" (ATWOOD, 1990, p. 72). Given that dystopias about the near-end of the species attempt to cover the whole planet, they inevitably adopt a discursive universalism. Such a stance would seem to be imaginable only at what is supposed to be the centre of one's cultural and political universe, which perhaps explains the displacement of Canada by the United States in her recent dystopias, or ustopias.

The degree to which Atwood elects not to nationalize Oryx and Crake and The Year of the Flood is conspicuously evident in the indeterminacy of their settings. Critics tend to hypothesize that the two novels take place in New England, New York, or the US Midwest. But as far as I am aware, no one has attempted to make the case that they are set in some unequivocally Canadian space like the Prairies or the Arctic, to say nothing of the author's own hometown-to which I will return in a moment. Canada's presence in Oryx and Crake seems to be limited to "high-grade Vancouver skunkweed" (ATWOOD, 2004c, p. 104), a "Gated Vacation Com- 
munity" in Moosonee (p. 217), and the fact that the Watson-Crick Institute's mascot is a "spoat/gider-one of the first successful splices, [which was] done in Montreal" (p. 242). If anything, the situation is even more dire in The Year of the Flood, where one of the rare Canadian references is to "the desolate Grand Banks of Newfoundland" (ATWOOD, 2009, p. 197). Much more common are allusions to transnational places or substances like "the Great Dead Zone in Lake Erie" (p. 196), “West Coast superweed” (p. 173), or "gated communities out west" (p. 392). It is indicative of the lack of spatial specificity in the novel that people do not relocate to California, Oregon, or British Columbia, but simply to "the West Coast" (p. 288), as if people treated moving to San Diego, the Napa Valley, or Haida Gwaii the same way. After all, considering how Texas supposedly has been affected by global warming, one presumes that southern California has not been left untouched by climate change. In any case, when one examines the erasure of Canadian space in the MaddAddam series in light of Atwood's public pronouncements about the evils of continentalism, one cannot help but sense that there is a tremendous disconnect between the novelist and the public intellectual.

Admittedly, there are different interpretations of Atwood's geopolitics in her MaddAddam novels, a trilogy that she recently concluded with the eponymous third volume, MaddAddam (2013). The well-known Canadian literary scholar Les Monkman (2005) contends that, in Oryx and Crake, Atwood "returns to the conventions of speculative fiction with a plot eerily anticipating the SARS epidemic of that same year while presenting an apocalyptic vision of a world destroyed by climate change, genetic manipulation, and segregated communities" (p. 16). However, as much as I admire Monkman's scholarship, I am not persuaded by his argument here. From my perspective, the connection between Atwood's novel and SARS (Severe Acute Respiratory Syndrome) is a case of wishful thinking. Atwood does not anticipate the SARS crisis, she misses it - possibly because she is so intent on capturing the universal, or at least the continental, instead of the local. In fact, the MaddAddam series illustrates why many scholars see genres like science fiction and historical fiction as escapist forms, a way of evading the complexities of the present.

The irony is that in 2003, the year Atwood published Oryx and Crake, her hometown was at the centre of a real epidemic, causing her "launch event in Toronto" to be cancelled and "elsewhere in the country people were alarmed when I coughed" (ATWOOD, 2006, p. 1). Thus one of the lessons of the SARS crisis, it would seem, is that we humans do not need to have conspiracies by transnational corporations and rogue scientists to be in deep trouble; we can get there all by ourselves - or perhaps with a little assistance by either God or nature, which wishes to punish us for our seemingly insatiable drive to consume or for 
some other unspecified transgression. As Atwood (2006) has observed, "Viruses are like interplanetary travellers; life forms are their planets. At some moments the aliens invade, and we have no protection against them because we didn't see them coming" (p. 2). The other lesson is that, despite the hegemony of globalized economics, we are not quite yet living in a postnational age. Like the events of September 11, 2001, the SARS epidemic demonstrated that national borders still matter. Soon after the outbreak, "Toronto was placed under an international travel advisory," film production came to a halt as "actors and film workers refused to travel to [the] city," and the hospitality industry was "devastated by a lack of business" (LAM \& LEE, 2006, p. 4). Among the groups that cancelled their conferences in Toronto at the last minute was the American Association for Cancer Research, "stranding thousands of scientists" (DAVIES, 2003). Finally, what the SARS crisis demonstrates is that world-historical events, even calamitous ones, can happen anywhere. They do not just occur in iconic places like New New York and its neighbouring gated compounds, although writers may increase the sales of their books by imagining that such is the case.

Before concluding, I must acknowledge another analysis of Atwood that challenges my reading. In his comprehensive review of The Year of the Flood, Fredric Jameson (2009) asserts that, in addition to her feminism and ecologism, "there is a category into which she squarely fits and without which she cannot fully be understood, a category of which at least 300 million English-speakers generally need to be reminded: she is a Canadian, and no little of her imaginative power comes from her privileged position above the border of the lower 48 . The Fall is not properly grasped unless it is understood to be a fall into Americanism." Jameson then quotes what he calls "the magnificent rant from [her 1972 novel] Surfacing" about everyone in North America being "'Americans,'" regardless of "'what country they're from"' (see also ATWOOD, 1994, p. 129), which suggests that he perceives a significant degree of continuity between the recent and the early Atwood, the one deeply influenced by texts such as George Grant's 1965 Lament for a Nation. But I wonder how Jameson can reconcile the notion that Atwood's Canadian citizenship is crucial to the comprehension of The Year of the Flood with the fact that, as Le Guin points out, the novel's "setting may be the upper Midwest of the US or Canada, but there is no geography, no history" (JAMESON, 2009). In particular, there is no Canada. I must say that I am far more receptive to the argument by the Italian literary scholar Eleonora Rao (2006) that, since the early 1990s, Atwood has been going through a "postnationalist phase" (p. 101), producing texts that "put into question narratives of national attachment by refusing to adhere to the limitations of the nation-state and its related discourses of territory and identity" (p. 112). That is, 
the most striking aspect about Canada's place in Atwood's latest novels is its lack of visibility.

One thinker that I believe helps us understand the evolution of the collective identity of Atwood's writing is the Danish critic Georg Brandes. In his 1899 essay "World Literature," which he first published in German, Brandes examines how writing is affected when an author goes from being a national writer to a world one. "Something unprecedented has arisen in our time," posits Brandes, "precisely because writers see before them the possibility of being known and read throughout the whole world. People begin to write for an invisible, abstract public, and this does damage to literary production" (BRANDES, 2009, p. 65). Brandes gives the example of Émile Zola and how "His great series of novels, Les Rougon-Macquart, was written for the French and is therefore carefully and concretely executed. His trilogy Lourdes, Rome, Paris, composed after he had achieved great fame, was written for the whole world, and for this reason is far more abstract than before" (p. 66). As he underlines, "Whatever is written for the whole world sacrifices strength and vigor for the sake of universal comprehensibility, it no longer carries the flavor of the soil" (p. 66). It is definitely hard not to notice the degree of abstraction in general and geographic non-specificity in particular in the MaddAddam novels. If one did not know Atwood's citizenship, it is unlikely that one would be led to conclude that the author is Canadian; instead, given the focus of both novels on what used to be the United States, one probably would deduce that she is American. Thus considering Atwood's image as fearless champion of Canadian cultural and political sovereignty, as reflected in her frequent altercations with Prime Minister Stephen Harper, the general absence of Canada in her most recent dystopias is at least curious. It certainly seems to suggest that Atwood the public intellectual is fighting a fight on which Atwood the novelist has given up. Or, to phrase it differently, not the least formidable of citizen Atwood's adversaries would appear to be Atwood the fiction writer.

\begin{abstract}
This essay examines how Margaret Atwood's recent dystopias Oryx and Crake and The Year of the Flood reflect a transnational turn in her fiction, which is a significant development both in light of her early work and her public image as a Canadian cultural nationalist.
\end{abstract}

Keywords: cultural nationalism; continentalism; dystopia; the transnational turn. 


\section{REFERENCES}

ATWOOD, Margaret. "The Art of Fiction CXXI." Interview with Mary Morris. Paris Review n. 117, p. 68-88, 1990.

Blind Faith and Free Trade. In: NADER, Ralph et al. The Case against Free Trade: GATT, NAFTA, and the Globalization of Corporate Power. San Francisco: Earth Island/ Berkeley: North Atlantic, 1993, p. 92-96.

. Foreword. In: LAM, Vincent; LEE, Colin. The Flu Pandemic and You: A Canadian Guide. Toronto: Doubleday Canada, 2006, p. 1-2.

Freeforall. 1987. In: Northern Suns, eds. David G. Hartwell; Glenn Grant. New York: TOR, 1999a, p. 17-24.

The Handmaid's Tale. 1985. Toronto: Seal, 1986.

The Handmaid's Tale and Oryx and Crake in Context. PMLA v. 110, n. 3, p. 513-17. 2004a.

. In Other Words: SF and the Human Imagination. Toronto: McClelland and Stewart, 2011.

"Interview: Elephants Are Not Giraffes: A Conversation with Margaret Atwood, More or Less about Northrop Frye." With Nick Mount. University of Toronto Quarterly, v. 81, n. 1, p. 60-70, 2012a.

. MaddAddam. Toronto: McClelland and Stewart, 2013.

Moving Targets: Writing with Intent 1982-2004. Toronto: Anansi, 2004b.

. Oryx and Crake. 2003. Toronto: Seal, 2004c.

. Second Words: Selected Critical Prose. Toronto: Anansi, 1982.

. Surfacing. 1972. Toronto: McClelland and Stewart, 1994.

SURVIVAL: A Demi-Memoir. In: Survival: A Thematic

Guide to Canadian Literature. Toronto: Anansi, 2012b,p. v-xii.

Survival: A Thematic Guide to Canadian Literature. 1972. Toronto: McClelland and Stewart, 2004d.

. "Survival, Then and Now." Maclean's, p. 54-58, 1 July 1999b. Time Capsule Found on the Dead Planet. In: I'm with the Bears, ed. Mark Martin. London: Verso, 2011, p. 191-193.

The Year of the Flood. Toronto: McClelland and Stewart, 2009. BARBER, John. "Atwood: 'Have I ever eaten maggots? Perhaps..." Globe and Mail 12 Sept. 2009, p. R1, R5.

BEER, Gillian. "Gardening God's Flooded Earth. Rev. of The Year of the Flood, by Margaret Atwood." Globe and Mail 12 Sept. 2009, p. R8. BRANDES, Georg. World Literature. 1899. Trans. Haun Saussy. In: The Princeton Sourcebook in Comparative Literature: From the European Enlightenment to the Global Present, eds. David Damrosch et alii. Princeton: Princeton UP, 2009, p. 61-66. 
BRAZ, Albert. "Erasing the Nation: Canada's National Literature in the Age of Globalization." Revista Canaria de Estudios Ingleses, n. 58, p. 15-26, 2008.

"The Literary Taxonomist: Margaret Atwood, Survival, and the Canadian Canon." Canadart, vol. 18, no. 1, p. 15-33, 2010. CASANOVA, Pascale. The World Republic of Letters. 1999. Trans. M. B. DeBevoise. Cambridge, MA: Harvard UP, 2004.

CSICSERY-RONAY, JR., Istvan. Dis-Imagined Communities: Science Fiction and the Future of Nations. In: Edging into the Future: Science Fiction and Contemporary Cultural Transformation, eds. Veronica Holinger; Joan Gordon. Philadelphia: U of Pennsylvania P, 2002, p. 217-37.

DAVIES, Kevin. "Coalition Forces and the Fog of War." Bio-IT World 9 May 2003. Available <http://www.bio-itworld.com/archive/050903/ firstbase.html> Accessed 5 Oct. 2012.

DENNISON, Stephanie; LIM, Song Hwee. Introduction: Situating World Cinema as a Theoretical Problem. In: Remapping World Cinema: Identity, Culture and Politics in Film, eds. Stephanie Dennison; Song Hwee Lim. London: Wallflower, 2006, p. 1-15.

EDUGYAN, Esi. Half-Blood Blues. Toronto: Thomas Allen, 2011.

ELLIOTT, Ellen. Publishing in Wartime. Toronto: Macmillans of Canada, 1941.

GAINES, Tarra. "Margaret Atwood Talks Satire, Sundance, and Science Fiction before Her Sold-out Inprint Event." CultureMap Houston 22 Jan. 2012.

Available $<$ http://houston.culturemap.com/news/entertainment/01-22-12margaret-atwood-talks-satire-sundance-and-science-fiction-before-her-soldout-inprint-event/> Accessed 10 Oct. 2012.

HENIGHAN, Stephen. When Words Deny the World: The Reshaping of Canadian Writing. Erin, ON: Porcupine's Quill, 2002.

JAMESON, Fredric. Then You Are Them. Rev. of The Year of the Flood, by Margaret Atwood. London Review of Books 10 Sept. 2009. Available <www.lrb.co.uk/v31/n17/fredric-jameson/then-you-are-them> Accessed 18 June 2012.

LAM, Vincent; LEE, Colin. The Flu Pandemic and You: A Canadian Guide. Toronto: Doubleday Canada, 2006.

LE GUIN, Ursula K. Rev. of The Year of the Flood, by Margaret Atwood. Guardian 29 Aug. 2009. Available <www.guardian.co.uk/ books/2009/aug29/margaret-atwood-year-of-flood> Accessed 2 Nov. 2011.

McCOY, Heath. Queen of Can-Lit Margaret Atwood Named 2013 Distinguished Visiting Writer. Available <http://www.ucalgary. ca/news/utoday/january9-2013/writer> Accessed 22 May 2013. 
MONKMAN, Leslie. English Canadian Citizenship in "The World Republic of Letters". Review: Literature and Arts of the Americas, v. 41, n. 1, p. 8-19, 2008.

PURDY, Al. Concerning Ms. Atwood. In: Beyond Remembering: The Collected Poems of Al Purdy, ed. Sam Solecki. Madeira Park, BC: Harbour, 2002, p. 496-497.

RAO, Eleonora. Home and Nation in Margaret Atwood's Later Fiction. In: The Cambridge Companion to Margaret Atwood, ed. Coral Ann Howells. Cambridge: Cambridge UP, p. 100-113, 2006.

SAWYER, Robert J. Relativity: Stories and Essays. Deerfield, IL: ISFIC, 2004.

WILSON, Robert Charles. A Dystopia Sketched in Crayon. Rev. of The Year of the Flood, by Margaret Atwood. Literary Review of Canada, v. 17, n. 8, p. 17, 2009.

WILSON, Edmund. Letter to Hugh MacLennan, 18 Nov. 1964. In: Letters on Literature and Politics 1912-1972, ed. Elena Wilson. New York: Farrar, Straus and Giroux, 1977, p. 633-634. 